\title{
The Effect of Brand Image and Price on Product Purchase Decisions at the Sewing House Akkhwat Makassar
}

\author{
Hasmiati $^{1 *}$, Ilham Thaief ${ }^{2}$, Muhammad Hasan $^{3}$, Muhammad Dinar ${ }^{4}, \operatorname{Rahmatullah}^{5}$ \\ 1,2,3,4,5 Pendidikan Ekonomi, Universitas Negeri Makassar \\ Email: hasmiatiltf98@gmail.com
}

(Received : 28 July 2020 ; revised : 14 August 2020 ; published : 23 September 2020 )

\begin{abstract}
This study aims to determine the effect of brand image and price on product purchase decisions at the Sewing House of Akhwat Makassar. This research is categorized as a type of quantitative descriptive research. The population in this study were all consumers who purchased products at the Makassar Sewing House in July 2019 as many as 101 consumers. Sampling was done by means of purposive sampling of 50 consumers. The method of data collection was done by using interview, questionnaire and documentation techniques. The analysis technique used is multiple linear regression analysis using SPSS 16.0 software. The results showed that the variables of brand image and price partially had a positive and significant effect on product purchasing decisions at the Sewing House for Women in Makassar. Simultaneously, there is a positive and significant influence between brand image and price variables on product purchasing decisions at the Sewing House for Women in Makassar.
\end{abstract}

Keywords: Brand Image, Price, and Purchase Decision.

Copyright (C) 2020 Universitas Negeri Makassar. This is an open access article under the CC BY license (http://creativecommons.org/licenses/by/4.0/)

\section{INTRODUCTION}

The dynamic and competitive development of the business world requires companies to make changes in orientation to the way they serve their customers, deal with competitors and issue products. Intense competition makes companies more innovative in issuing products that consumers like. The information age and knowledge revolution have caused problems for every individual and organization (Hasan, 2018).

In fulfilling the needs and desires of life, humans are never satisfied (Rahmatullah \& Inanna., 2017). Human needs vary in quantity, quality and style and continue to increase with the times. As we know, the product offer is very diverse and many, one of which is the basic necessity of clothing or clothing. The clothes or clothing needed will vary according to the activities carried out daily. As time goes by, the trend of dressing is increasingly varied and now what is currently popular in the midst of people's life is the trend of wearing the hijab. 
In addition to covering the genitals, Muslim clothing and hijab have become a fashion trend that continues to develop. Various hijab creations that aim to support the appearance of Muslim women to make them look more attractive and tidy, nowadays consumers are so spoiled by the many models of Muslim clothing and hijab making them more selective in making their choices before making a purchase decision. Like a war, business competition in the fashion sector also demands the existence of superior weapons. Various efforts have been made by the company in maintaining its business in order to exist and be able to survive in a situation of increasing competition, including by providing informal education. As well as providing regular training to employees in improving their skills (Henni Zainal, Muhammad Rakib, Andi Idham Ashar, Darmawati Manda, Andi Tenry Sose, 2020).

According to Inanna et.al. (2020) the informal education process has a strategic role in developing human resources. To provide a sustainable competitive advantage, resources must be valuable, scarce, and do not have the same substitutes (Henni Zainal, Parinsi, Indonesia, Hasan, \& Makassar, 2018). And with the development of human resources the company can easily make improvements and product innovation aimed at mempertahank an image of the corporate brand. Human resource development is carried out by looking at employee performance by paying attention to the relationship between employees (Rakib, Zainal, Farwita, \& Yusriadi, 2019).

Brand image is how a brand affects the perception, views of society or consumers of the company or its products. The better the brand image of a product or service offered, it will have an impact on consumer purchasing decisions.(Suryati, 2015) said that brand image is a representation of the overall perception of a brand and is formed from information and past experiences with that brand. Meanwhile, according to Kotler and Keller in (Darwis, 2017) brand image is a process where a person selects, organizes, and interprets information input to create a meaningful image.

Brand image refers to a memory scheme of a brand that contains consumer interpretations of the attributes, advantages, uses, situations, users and characteristics of marketers or characteristics of the manufacturer of the product or brand. So it can be concluded that the brand image is what consumers think and feel when they hear or see the name of a brand.

Companies that are engaged in selling Muslim clothing are increasing, this is evidenced by the establishment of several Muslim clothing stores in the city of Makassar. One company in the growing fashion sector that can even compete with other companies is the Makassar Sewing House or better known as RJA, which is headquartered on Jl. Toddopoli 17 No 88 B. In 2012, the sewing house for adults in Makassar only produced and sold in Toddopuli, as time went on, the sewing house for adults in Makassar was growing. This is evident in 2017 that several branches have been established in the city of Makassar, namely the Sentral, Antang, Perintis, Alauddin and several branches in areas such as sidrap, sinjai and bone. 
In addition to the brand image, price is also very important to consider before making a purchase decision because price is the exchange rate in the form of money that must be paid by consumers to producers to obtain the benefits contained in a product or service. Price can provide an overview of the quality of a product, in this case consumers consider a positive relationship between price and product quality.

Price also has an important role in marketing, both for sellers and buyers (Fatihudin, 2019) said that price is a means of exchange for measuring the value of money contained in a good or service, while money is used as a measuring tool. Pricing is critical to the success of the products offered (Andi Hafidah, 2015).

Similar to other companies, the Sewing House of Akhwat Makassar also sets product prices according to the difficulty level in making a fashion model, the size and the amount of material needed in the manufacture of the product. In addition, the Sewing House for Akhwat Makassar also provides discounts as a strategy for selling its products. Discounts are a sales strategy that is in great demand and makes consumers interested in the products offered (Dhiranty, Suharjo, \& Suprayitno, 2017; Usaha \& Pasar, 2018).

A buying decision process is not just knowing the various factors that will affect the buyer, but based on the role in the purchase and the decision to buy. In the purchase decision process, consumers are often faced with two or more parties who play a role in the buying process.

Kotler dan Amstrong in (Labiro, 2017) also define that purchasing decisions are the stage in the buyer's decision-making process where consumers actually buy. Decision making is an individual activity that is directly involved in obtaining and using the goods offered.

The decision-making process begins with a need that is trying to be fulfilled. Fulfillment of this need is related to several alternatives so it is necessary to conduct an evaluation aimed at obtaining the best alternative from consumer perceptions. In the process of comparing consumers requires information whose amount and level of importance depends on the needs of the consumer and the situation he is facing. Purchasing decisions will be made using the principle of balancing the positive side with the negative side of a brand ( compensatory decisions rule) or finding the best solution from a consumer perspective (non-compensatory decisions rule), which after consumption will be re-evaluated (Firmansyah, 2016).

Consumers are a major factor in the ongoing life of a company, therefore it is very important for a company to understand every consumer behavior, especially in today's era consumers are so easy to get information about a product so that companies are also required to be able to offer interesting information in order to get the attention of consumers. . Now consumers have higher mobility and there are more alternatives for making purchases, including online purchases. Consumers tend to choose products of comparable quality to the price or at affordable prices but still get products of good 
quality so that prices can be taken into consideration in addition to the brand image of a product before making a purchase decision.

Considering that brand image and price are factors that influence purchasing decisions, the title "The Influence of Brand Image and Price on Product Purchasing Decisions at the Sewing House of Makassar's Akhwat" was carried out.

\section{METHOD}

This research is a quantitative descriptive study, namely research on the data collected and expressed in numbers which aims to examine the effect of brand image (X1) and price (X2) on product purchase decisions at the Sewing House of Akhwat Makassar (Y). Data were collected using a questionnaire or questionnaire. The population in this study were all consumers who purchased products at the Sewing House of Akhwat Makassar in July 2019 as many as 101 consumers with a sample size of 50 consumers. The independent variable in this study is brand image (X1) and price (X2), while the dependent variable in this study is the purchase decision (Y). Measurement of variables in this study using a Likert scale. Respondents provide answers to four alternative choices available in the questionnaire provided for each statement. The instrument test used was data analysis consisting of validity and reliability tests. The data analysis technique used is multiple linear regression analysis and hypothesis testing with the $t$ test and F test using SPSS 16.0 software.

\section{RESULT AND DISCUSSION}

The validity test is used to test the extent to which the accuracy of the measuring device can reveal the concept of the symptoms or events being measured. In addition, the validity test is also used to see whether the variables or statements submitted represent all the information that should be measured. If $r$ count $\geq$ from $r$ table then the statement is declared valid. If $r$ count $\leq r$ table, then this means that the statement item is declared invalid. According to Siregar (2016: 162) u ji validity shows the extent to which a measuring instrument is able to measure what you want to measure (valid measure if it successfully measures the phenomenon) ". The results of this study indicate that all statement items (variables) with a sample of 50 respondents have $r$ count $\geq$ of $r$ table (0.000) and are positive. With entire item statement is thus declared invalid.

Reliability test is used to determine the consistency of measuring instruments in use, or in other words, these measuring instruments have consistent results when used many times in different times. For the reliability test, the Cronbach Alpha was used, where all instruments can be said to be reliable (reliable) if they have a state coefficient or alpha of 0.6 or more. The reliability test results can be seen in the following table 1 . 
Hasmiati: The Effect of Brand $\mid 61$

Table 1. Reliability Test

\begin{tabular}{lll}
\hline Variable & Cronbach Alpha & Information \\
\hline Brand Image & 0,866 & Reliabel \\
Price & 0,908 & Reliabel \\
Buying decision & 0,808 & Reliabel \\
\hline
\end{tabular}

Source: Data Processing Results, 2020

The Smirnov Kolmogrof normality test is used to determine whether the residual value is normally distributed or not. If the significant value (Sig) $\geq 0.05$, the residual value is normally distributed and if the significant value (Sig) $\leq 0.05$ then the residual value is not normally distributed. The results of the normality test can be seen in the following table:

Table 2.Uji Normality

\begin{tabular}{lllc}
\hline \multicolumn{1}{c}{ Variable } & $\begin{array}{l}\text { Kolmogrof } \\
\text { Smirnov Test }\end{array}$ & $\begin{array}{l}\text { Asymp.Sig. (2- } \\
\text { Tiled) }\end{array}$ & Information \\
\hline Brand Image & 1,135 & 0.152 & Normal \\
Price & 0.967 & 0.307 & Normal \\
Buying decision & 0.972 & 0.301 & Normal \\
\hline
\end{tabular}

Source: Results of Data Processing, 2020

The results of the normality test show that the significant value (Sig) of brand image is 0.152 ; price of 0.307 and a purchase decision of $0.301 \geq 0.05$, it can be stated that the residual value is normally distributed.

This study uses multiple linear regression analysis using the assistance of the IBM SPS S Statistics version 16. The objective is to prove the hypothesis regarding the effect of the independent variables (brand image and price) on the dependent variable (purchase decision). The results of multiple linear regression analysis can be seen in the following table:

Table. 3 Linear Regression Analysis Test

\begin{tabular}{|c|c|c|c|c|c|}
\hline \multirow{2}{*}{ Model } & \multicolumn{2}{|c|}{ Unstandardized Coefficient } & $\begin{array}{l}\text { Standardized } \\
\text { Coefficient }\end{array}$ & \multirow[t]{2}{*}{$\mathbf{T}$} & \multirow[t]{2}{*}{ Sig } \\
\hline & B & Std.Error & Beta & & \\
\hline (Constant) & 3,328 & 3,592 & & 0.926 & 0.359 \\
\hline $\begin{array}{l}\text { Brand } \\
\text { Image }\end{array}$ & 0.590 & 0.098 & 0.578 & 6,012 & 0,000 \\
\hline Price & 0.341 & 0.088 & 0.374 & 3,889 & 0,000 \\
\hline
\end{tabular}

Source: Data Processing Results, 2020 
62 Pinisi Business Administration Review

Volume 2 Number 2, September 2020. Pages 57-68

Based on Table 3, it is obtained that the value of a (constant) is 3.328 , the coefficient of $\mathrm{X} 1$ is 0.590 , and $\mathrm{X} 2$ is 0.341 when entered into the regression equation, the following equation is obtained:

a. The constant value of 3.328 means that if X1 (brand image) and X2 (price) the value is 3.328. The regression coefficient value $\mathrm{X} 1$ (brand image) is 0.590 , meaning that if the other independent variables are fixed and the brand image has increased by $1 \%$, then Y (purchase decision) will increase by 0.590 .

b. The coefficient is positive, meaning that there is a positive relationship between brand image and product purchase decisions at the Sewing House for Women in Makassar, the better the brand image, the higher the purchase decision.

c. X2 regression coefficient value (price) of 0.341 means that if the other independent variables fixed and price changes increase of $1 \%$, then $\mathrm{Y}$ (purchase decisions) will be increased by 0.341 . The coefficient is positive, it means there is a positive relationship between price and product purchasing decisions at Home Sewing Akhwat Makassar, the better the price seca ra simultaneous positive influence and significant on product purchasing decisions at Home Sewing Akhwat Makassar.

The $\mathrm{F}$ test (simultaneous) is used to determine the effect together (simultaneously) of the independent variables consisting of brand image and price on product purchase decisions at the Sewing House of the Akhwat Makassar. Oversight mbilan decision simultaneously test (test F), if the value of $F$ count $\geq$ $\mathrm{F}_{\text {tables }}$ and significant value $\leq 0.05$ then the price of brand image and influence simultaneously (together) on product purchasing decisions at Home Sewing Akhwat Makassar. On the other hand, if the calculated $F$ value $\leq F$ table and the significant value $\geq$ 0.05 then simultaneously (together) the brand image and price do not affect the product purchase decision at the Sewing House of the Akhwat Makassar. The results of processing obtained the value of Fcount (77.677) $\geq$ F table (3.19) with Sig F (0.000) $\leq$ (0.05). So, you can sew a Makassar Birthday. The results of the processing concluded that the variable brand image and price simultaneously had a positive and significant effect on product purchasing decisions at the Sewing House of Nursing Makassar.

The $t$ test (partial) is used to determine the effect of individually variable brand image and price on product purchasing decisions at the Sewing House of the Women of Makassar. Decision making partially test ( $t$ test), if the value of $t_{\text {count }} \geq t_{\text {table }}$ and significant value $\leq$ of 0.05 then the variable brand image and price partially affect the decision to purchase products at the Sewing House of the Akhwat Makassar. The t test results can be seen in the following table: 
Hasmiati: The Effect of Brand $\mid 63$

\begin{tabular}{|c|c|c|c|c|c|}
\hline \multirow{2}{*}{ Model } & \multicolumn{2}{|c|}{ Unstandardized Coefficient } & $\begin{array}{l}\text { Standardized } \\
\text { Coefficient }\end{array}$ & \multirow[t]{2}{*}{$\mathbf{T}$} & \multirow[t]{2}{*}{ Sig } \\
\hline & $\mathbf{B}$ & Std.Error & Beta & & \\
\hline (Constant) & 3,328 & 3,592 & & 0.926 & 0.359 \\
\hline 1 Brand Image & 0.590 & 0.098 & 0.578 & 6,012 & 0,000 \\
\hline Price & 0.341 & 0.088 & 0.374 & 3,889 & 0,000 \\
\hline
\end{tabular}

Table. $4 \mathrm{t}$ test

Source: Results of Data Processing, 2020

The $t$ test results in the table indicate that:

a. The results of the data processing above obtained tcount $(6,012) \geq$ ttable $(1.679)$ and a sig value of 0,000 , which means that the brand image variable (X1) has a positive and significant effect on the variable product purchasing decisions at the Sewing House of the Akhwat Makassar.

b. Results if the $d$ ata above obtained value of $t$ arithmetic (3.889) $\geq t$ table (1.679) and sig 0,000 means a price variable (X2) influential positive and significant to the variable k eputusan purchase products at Home Sewing Akhwat Makassar.

c. The table shows that by looking at the coefficient value of each independent variable, namely brand image and price. Brand image has a regression coefficient of 0.590 and price has a regression coefficient of 0.341 . It can be concluded that the brand image variable is the dominant variable in influencing consumer decisions because it has a larger regression coefficient.

The coefficient of determination test is used to find out how much influence the brand image and price have on product purchase decisions at the Sewing House of Nursing Makassar. The magnitude of the contribution of brand image and price to purchasing decisions is known from the coefficient of determination of 0.758 or $75.8 \%$. This means that $75.8 \%$ of the variable. The purchase decision is explained by the brand image and price variables, while the remaining $24.2 \%$ is explained by other factors outside of this study.

\section{Partial influence of brand image on product purchase decisions at the Sewing House of the Akhwat Makassar}

The results showed that the brand image variable had a positive and significant effect on product purchase decisions at the Sewing House of Akhwat Makassar, so it could be said that brand image was one of the factors that sufficiently influenced purchasing decisions, with a good brand image, people would believe more in the brand image. Products at the Sewing House for the Nursing Makassar so many people choose 
them. This means that if the brand image variable is increased, the decision to purchase products at the Sewing House for Women in Makassar will increase. The higher the brand image that the company has, the more likely it will increase the decision to buy products at the Sewing House for Women in Makassar.

This result is in line with research conducted by (Romadhoni, 2015) which indicates that a brand image is a representation of the overall perception of a brand and is formed from information and past experiences with that brand. Consumers who have a positive image of a brand are more likely to make purchases because a good brand image can increase consumer purchasing decisions. Based on this, he concluded that there was a significant influence on brand image on purchasing decisions.

\section{Partial effect of price on product purchase decisions at the Sewing House for Women in Makassar}

The results showed that the price variable has a positive and significant effect on product purchase decisions at the Sewing House for Women in Makassar, so it can be said that the more affordable the price of a product that is owned by the company, the more likely it will increase the decision to purchase products at the Sewing House of the Akhwat Makassar. In addition, pricing that is affordable will make it easier for consumers to make considerations when making purchases so that consumers can get a discount, and with a discount, it will allow consumers to make repurchases in the future.

This result is in line with research conducted by (Ulam, 2019) which states that price is a very important strategy in marketing, if the price set by a company is right and in accordance with the purchasing power of consumers, it will get greater attention from consumers. The. If the product price is low, the demand for a product offered will increase, but on the other hand, if the product price is high, the demand will decrease. Based on this, he concluded that that price has a positive and significant influence on purchasing decisions..

\section{Simultaneous influence of brand image and price on product purchasing decisions at the Sewing House for Women in Makassar}

Based on the test results, the $\mathrm{F}$ test shows that the brand image and price simultaneously influence the product purchase decision at the Sewing House for Women in Makassar. This can be seen from the results of the calculation of data processing, it is obtained that the value of Fcount (77.677) $\geq$ Ftable (3.19) with Sig F $(0.000) \leq(0.05)$.

From the research, it is known that brand image has an influence on product purchasing decisions. This means that the brand image of the product at the Makassar Sewing House is fully accepted by consumers so that the Makassar Sewing House needs to maintain the quality of its products so that these products will still be accepted by consumers and will be more developed so that more consumers will know the product 
Hasmiati: The Effect of Brand $\mid 65$

brand of the Makassar Nursing Home. Apart from that, the Sewing House for Akhwat Makassar also utilizes social media to carry out promotions so that it can be widely recognized by consumers which will have an impact on increasing purchasing decisions. Not only that, price also has an influence on purchasing decisions. This means that affordable product prices will attract consumers' attention to make purchasing decisions. Therefore, the Makassar Nursing Home must maintain the stability of the price of each product from competition with other similar products so that consumers are satisfied with the balance of price and quality of the product obtained.

These results are in line with the research conducted by (Darwis, 2017) in his thesis entitled "The Influence of Brand Image and Prices on Purchasing Decisions of Toyota Avanza at PT. Hadji Kalla, Alauddin Makassar branch, "said that the increasingly dynamic and competitive business development requires companies to improve the quality of their products, this is done to maintain their brand image. Here the brand has distinctive characteristics and it is with these distinctive characteristics that can distinguish one product from another. Companies that have a good brand image in the eyes of consumers will have an impact on purchasing decisions. Apart from brand image, price is also very influential on purchasing decisions, because by looking at the price, consumers will be easily influenced to buy a product. Especially if the product offered has a price that is directly proportional to its quality. Based on this, he concluded that brand image and price had a positive and significant effect on purchase decisions.

\section{CONCLUSION}

Based on the results of the partial analysis or t test, it shows that the independent variable, namely brand image (X1), has a positive and significant effect on the dependent variable, namely the purchase decision (Y) of the product at the Sewing House for Women in Makassar. This is evidenced by the obtained tcount $(6,012) \geq \mathrm{t}$ table $(1,679)$ and a sig value of 0,000 . The result of the partial analysis or t test shows that the independent variable, namely price (X2), has a positive and significant effect on the dependent variable, namely the purchase decision $(\mathrm{Y})$ of the product at the Sewing House for Women in Makassar. This is evidenced by the obtained tcount (3.889) $\geq \mathrm{t}$ table (1.679) and a sig value of 0.000. The result of the simultaneous analysis or the $\mathrm{F}$ test shows that the independent variables, namely brand image (X1) and price (X2) simultaneously have a positive and significant effect on product purchasing decisions (Y) at the Sewing House of Akhwat Makassar. This is evidenced by the processing results obtained by the value of Fcount (77.677) $\geq$ Ftable (3.19) and the value of Sig F $(0.000) \leq(0.05)$. The result of the analysis of the coefficient of determination obtained an adjusted $R$ square of 0.758 or $75.8 \%$. This means that $75.8 \%$ of the variables of brand image and price have an effect on product purchase decisions at the Sewing 
House for Women in Makassar. While the remaining $24.2 \%$ is influenced by other variables outside the regression model in this study.

\section{BIBLIOGRAPHY}

Andi Hafidah. (2015). Analisis biaya dan pendapatan produksi jagung marning. Agrokompleks, $4(9)$.

Darwis, E. G. (2017). Pengaruh Brand Image dan Harga terhadap Keputusan Pembelian Mobil Toyota Avanza pada PT. Hadji Kalla Cabang Alauddin Makassar. Universitas Negeri Islam Alauddin Makassar.

Dhiranty, A., Suharjo, B., \& Suprayitno, G. (2017). An Analysis on Customer Satisfaction , Trust and Loyalty TOWARD ONLINE SHOP ( A Case Study of Tokopedia . com ), 3(32), 101-110.

Fatihudin, D. \& M. A. F. (2019). Pemasaran Jasa (Strategi Mengukur Kepuasan dan Loyalitas Pelanggan). Yogyakarta: Deepublish.

Firmansyah, D. (2016). Pengaruh inovasi produk dan kreativitas terhadap kinerja usaha bisnis pada distro clothing di kawasan trunojoyo bandung.

Hasan, M. (2018). Pendidikan Informal: Bagaimana Pendidikan Ekonomi Membentuk Pengetahuan Pada Bisnis Keluarga. JEKPEND Jurnal Ekonomi Dan Pendidikan, 1(2).

Henni Zainal, Muhammad Rakib, Andi Idham Ashar, Darmawati Manda, Andi Tenry Sose, I. S. (2020). Strategy of human resources development in improving performance Apparatus in the Bone Regency Regional Inspectorate. Pinisi Business Administration Review, 2(1).

Henni Zainal, U. I. T., Parinsi, W. K., Indonesia, S. P., Hasan, M., \& Makassar, U. N. (2018). The Influence Of Strategic Assets And Market Orientation To The Performance Of Family Business In Makassar City, Indonesia, 17(6), 1-9.

Inanna dkk. (2020). Silk Weaving As A Cultural Heritage In The Informal Enterpreneurship Education Perspective. Makassar. In Badan Penerbit Universitas Negeri Makassar.

Labiro, M. K. (2017). Pengaruh Citra Merek, Harga, dan Kualitas Produk pada Keputusan Pembelian Produk Purbasari Lipstick Matte (Studi Kasus pada Mahasiswi Universitas Sanata Dharma Yogyakarta. Universitas Sanata Dharma Yogyakarta.

Rahmatullah \& Inanna. (2017). Ekonomi Berkarakter Eco-Culture. In Badan Penerbit Universitas Negeri Makassar.

Rakib, M., Zainal, H., Farwita, S., \& Yusriadi, Y. (2019). The Improvement of Employees ' Performance in South Sulawesi , Indonesia, (November). 
Hasmiati: The Effect of Brand $\mid 67$

https://doi.org/10.35940/ijrte.D7761.118419

Suryati, L. (2015). Manajemen Pemasaran: Suatu Strategi dalam Meningkatkan Pemasaran. Yogyakarta: Deepublish.

Usaha, P. M., \& Pasar, O. (2018). Pengaruh modal usaha, orientasi pasar, dan orientasi kewirausahaan terhadap kinerja ukm kota makassar, 5(1), 95-111. 
68 | Pinisi Business Administration Review

Volume 2 Number 2, September 2020. Pages 57-68 